\title{
INFLUENCE OF ORTHOSTATIC LOADING PROBES ON PUMPING FUNCTION OF THE HEART OF ATHLETES WITH DISABILITIES OF HEALTH
}

\section{INFLUENCIA DE LAS SONDAS DE CARGA ORTOSTÁTICA SOBRE LA FRECUENCIA CARDÍACA DE ATLETAS CON DISCAPACIDADES}

\author{
L.I. Vakhitov ${ }^{1}$, T.L. Zefirov ${ }^{1}$, I.Kh. Vakhitov ${ }^{1}$ \\ ${ }^{1}$ Kazan Federal University, 420008, Kazan, ul. Kremlyovskaya, 18 \\ Bulat.vakhitov.1989@mail.ru
}

Enviado: 27 de junio de 2019

Aceptado para publicar: 30 de julio de 2019

Publicado: 8 de agosto de 2019

\section{abstract}

In the present research, the reaction of the pumping function of the heart (PFH) of disabled athletes to an orthostatic test was studied. Analysis of indicators of the pumping function of the heart was carried out in two stages. At the first stage, the PFH indicators of disabled athletes in the prone position were investigated. In the second stage, the urgent reaction of the indicators of the pumping function of wheelchair basketball players was carried out for 5-20 seconds after an active transition from a prone position to a sitting position. It was revealed that in wheelchair basketball players with amputated lower limbs, the difference in heart rate parameters during an orthostatic test was significantly higher than in basketball players with atrophy of the lower limbs. Basketball players with amputated lower limbs react to large changes in body position with active changes in body position than athletes with atrophied lower limbs.

Keywords: wheelchair basketball players, active orthostatic test, heart rate, stroke volume, pumping function of the heart.

En la presente investigación, se estudió la reacción de la función de bombeo del corazón (PFH) de atletas discapacitados a una prueba ortostática. El análisis de los indicadores de la función de bombeo del corazón se realizó en dos etapas. En la primera etapa, se investigaron los indicadores de PFH de atletas discapacitados en posición prono. En la segunda etapa, la reacción urgente de los indicadores de la función de bombeo de los jugadores de baloncesto en silla de ruedas se llevó a cabo durante 5 a 20 segundos después de una transición activa de una posición propensa a una posición sentada. Se reveló que en los jugadores de baloncesto en silla de ruedas con miembros inferiores amputados, la diferencia en los parámetros de frecuencia cardíaca durante una prueba ortostática fue significativamente mayor que en los jugadores de baloncesto con atrofia de los miembros inferiores. Los jugadores de baloncesto con miembros inferiores amputados reaccionan a grandes cambios en la posición del cuerpo con cambios activos en la posición del cuerpo que los atletas con miembros inferiores atrofiados.

Palabras clave: jugadores de baloncesto en silla de ruedas, prueba ortostática activa, frecuencia cardíaca, volumen sistólico, función de bombeo del corazón. 


\section{Introduction}

According to the World Health Organization, people with disabilities account for about $10 \%$ of the world's population. The practical experience of domestic and foreign specialists shows that the most effective method of rehabilitation of the disabled is systematic physical culture and sports $[1,2,4,7,10,12,14,15]$.

Of the few studies that characterize Paralympics with lesions of the musculoskeletal system, only a few are devoted to basketball in wheelchairs and, in general, are only aimed at improving the training process. Basketball as a sport discipline has its characteristics, which is due to the nature of training and fights - the actions are sharply high-speed, often interrupted by pauses. Athletes with the consequences of injuries or diseases of the spinal cord during the performance of technical actions are most often used only the upper shoulder girdle or tree limbs, depending on the level and degree of damage, a limited number of muscles of the back and abdomen may also be involved $[5,6,8,9,15]$. Persons with various lesions of the musculoskeletal system have different morphofunctional and psychophysiological indices, which have not been sufficiently investigated. A considerable interest among researchers is the study of the patterns of change in the pumping function of the heart when performing orthostatic tests $[2,3,4,10,11,13,16]$.

The idea of using a change in the position of the body in space as an input for the study of the functional state of the body has been implemented in the practice of functional diagnostics for a long time. Orthostatic tests play a significant role in the hemodynamics of disabled athletes, since changing the position of the body in space is natural for basketball in wheelchairs. Probably, there is no function of the organism whose parameters would not change with the active transition from a horizontal position to a vertical one. This question has been studied by several researchers and is currently accumulated in certain material. However, changes in the parameters of the pumping function of the heart during an active transition from a position lying in a position sitting at basketball players, wheelchairs remain not sufficiently studied.

The purpose of these studies was to study the peculiarities of the change in the pumping function of the heart at basketball playerswheelchairs when performing an orthostatic test.

\section{Research objectives:}

1. To study the response of the heart rate of athletes with disabilities with various injuries to the lower extremities, with the active transition from the position of lying to the sitting position;

2. To analyze the peculiarities of the UOC changes to the orthostatic test depending on the degree of damage to the lower extremities.

\section{Methods of Research}

The research was conducted among athletes with limited health capabilities of the basketball team "Wings of Bars". The total number of athletes surveyed was 20 . Athletes were conventionally divided into two groups. The first group included athletes with amputations of the lower extremities ( 9 people). The second group was made up of 11 people with atrophy of the lower extremities. The study of the parameters of the pumping function of the heart (PFH) was conducted in two stages. At the first stage, the PFH performance indicators of disabled athletes were studied in the lying position. In the second stage, the study of the urgent reaction of indicators of the pumping function of basketball players was studied within 5 to 20 seconds after an active transition from a lying position to a sitting position.

To assess the validity of the differences, the standard values of the Student's t-test were used.

\section{Method of Registering a Program}

Among the rheographic methods for determining the heart rate, the most widely used method is the tetrapolar thoracic rheography of Kubichek [10] in various modifications. The non-invasive nature of the method, its prostate and its availability for practical application make it one of the most promising methods for determining the frequency of heart rate.

Electrodes are superimposed according to the scheme; Two current electrode: the first - on the head in the field of the forehead, the second - on the shin above the ankle joint, 2 measuring electrodes: the first - in the neck at the level of the 7 th cervical vertebra, the second - in the region of the chest at the level of the bladder process.

In the complex "Rodin-500" the thoracic tetrapolar rheography was used as the basic medical technique. The main advantages of the method are high informativeness, complete safety for the patient, the possibility of continuous monitoring, etc. Repressure for computer analysis RPKA 2 - 01 TU 9442-002-00271802-95 is intended for work in the hardware and software complexes of medical purposes.

The device is recommended for use in medical practice by the Committee on new medical equipment of the Ministry of Health of the Russian Federation. (Minutes No. 5 dated June 13, 2015). Certificate of conformity of ROSS RU. $0001.11 \mathrm{IMO} 2$ №3434630.

The results of their research and their discussion For athletes with amputation of the lower limbs, the heart rate in the lying position was $77.2 \pm 1.4$ (Table 1.). When active from the position of lying to the sitting position, the heart rate increased by 
$7.3 \pm 1.2$ beats $/ \min (\mathrm{P}<0.05)$ compared with the baseline data and amounted to $84.5 \pm 1.8$. The heart rate at basketball players with atrophy of the lower extremities in the lying position was $71.3 \pm$ 1.8 beats/min. When active from the position of lying to the sitting position increased to $75.7 \pm 2.1$ and / minute. The response of the heart rate to the change of body position at athletes with atrophy of the lower extremities with an active transition from the position of lying to the sitting position was $4.4 \pm 1.6$ beats $/ \mathrm{min}(\mathrm{P}<0.05)$. This reaction of heart rate reduction to change the body position was $2.9 \pm 1.3$ beats/min less than the response of the heart rate to the change of body position in athletes with lower limb amputation $(\mathrm{P}<0.05)$. The reduction in heart rate in the range of 4 to 12 beats/min, according to scientists, indicates reduced tonus of the sympathetic department of the autonomic nervous system.

The impact of blood on athletes with amputation of the lower extremities, in the lying position, was $54.3 \pm 1.6 \mathrm{ml}$ (Table 2.). After the active transition from the position of lying to the sitting position, the shock of blood basketball players and wheelchairs decreased to $45.7 \pm 1.9 \mathrm{ml}(\mathrm{P}<0.05)$. Consequently, with the active transition from the position of lying to the sitting position, the reaction of the impact volume of blood of athletes with amputation of the lower extremities was 8.6 $\pm 1.4 \mathrm{ml}(\mathrm{P}<0.05)$. In basketball players with lower limb atrophy, the UOC in the lying position was $61.8 \pm 1.9 \mathrm{ml}$ with an active transition from a lying position to a sitting position dropped by 4.3 $\pm 1.7 \mathrm{ml}$ and amounted to $57.5 \pm 2.1 \mathrm{ml}$, which significantly differs from the reaction of systolic ejection of athletes with amputation of the lower extremities by $4.3 \pm 1.6 \mathrm{ml}(\mathrm{P}<0.05)$.

\section{Findings}

The orthostatic reactions of the body of athletes with disabilities are related to the fact that when a body position changes (from horizontal to vertical), a significant amount of blood is deposited in its lower half. As a result, the venous return of blood to the heart deteriorates, in this connection, in our opinion, the impact volume of blood decreases. Compensation for this adverse effect is primarily due to the proliferation of cardiac contractions. Also, an important role belongs to changes in vascular tone. This reorganization of central hemodynamics is characteristic of both groups of studying disabled athletes. The use of orthostatic prophylaxis reveals the hyperpsimato-adrenergic type of reaction and reflects a significant dissolution of the sympathetic department of the autonomic nervous system.

As our studies have shown, heart rate and UOC are undergoing major changes in athletes with lower limb amputation than athletes with atrophy of the lower extremities. The revealed difference is, in our opinion, reduced by the volume of circulating blood at basketball players, with amputated limbs. Changes in the pumping function of the heart of athletes with atrophy of the lower extremities are more associated with a violation of the tropic of the lower extremities, which in turn leads to severe violations of venous outflow.

Table 1. Changes in heart rate at basketball players - wheelchairs when performing the orthostatic test

\begin{tabular}{|c|c|c|c|}
\hline \multirow{2}{*}{ Group of surveyed } & \multicolumn{3}{|c|}{ Heart rate (ud / min) } \\
\cline { 2 - 4 } & Lying down & Sitting & Difference \\
\hline Athletes with amputation of the lower extremities & 77,2 & 84,5 & 7,3 \\
& $\pm 1,4$ & $\pm 1,8$ & $\pm 1,2$ \\
\hline Athletes with atrophy of the lower extremities & 71,3 & 75,7 & 4,4 \\
& $\pm 1,8$ & $\pm 2,1$ & $\pm 1,6$ \\
\hline
\end{tabular}

Table 2. Changes in UOC at basketball players - wheelchairs when performing the orthostatic test

\begin{tabular}{|c|c|c|c|}
\hline Group of surveyed & \multicolumn{3}{|c|}{ UOC (ml) } \\
\cline { 2 - 4 } & Lying down & Sitting & Difference \\
\hline Athletes with amputation of the lower extremities & 54,3 & 45,7 & 8,6 \\
& $\pm 1,6$ & $\pm 1,9$ & $\pm 1,4$ \\
\hline Athletes with atrophy of the lower extremities & 61,8 & 57,5 & 4,3 \\
& $\pm 1,9$ & $\pm 2,1$ & $\pm 1,7$ \\
\hline
\end{tabular}

\section{Conclusions}

1. In basketball players with amputated lower extremities, the difference in heart rates during orthostatic testing is significantly higher than that of basketball players with atrophy of the lower extremities.

2. Basketball players with amputated lower limbs for active body position change react with large changes in UOC than athletes with atrophied lower limbs.

\section{Acknowledgments}

The work is performed according to the Russian Government Program of Competitive Growth of 
Kazan Federal University.

\section{References}

1. Brukhovetsky A.C. Spinal Cord Injury: Cell Technologies in Treatment and Rehabilitation 9 Bryukhovetsky AS Moscow: Practical Medicine, 2010. - 341 p.

2. Vakhitov I.H. Changes in the impact volume of blood of young athletes in the recovery period following the Harvard steptest // Theor. and practice FK.- 1999.- No. 8.- S. 30-32

3. Vinogradov VI, Katushchuk G.I., Rylnikov P.A. Manual bicycle ergometry for patients with lower leg cramps .// Sec. tr Prosthetics and prosthetics, - Moscow: TsNIIPP, 1986, ed. 75, p.127-132.

4. Verich G. Features of hemodynamics in the disabled - athletes with damage to the musculoskeletal system / G. Veric, O. Lukovskaya, Yu. Vdovichenko, O. Kovalenko // Science in Olympic sports. 2002. - No. 2. - p.53-56.

5. Sakharova O.V. Integrated treatment using adaptive sports in the rehabilitation of patients with vertebral and spinal traumas: author's abstract. dis ... Cand. honey Sciences / Sakharova O.V...- Perm, 2005.-23 p.

6. Khramov V.V. Medical and sociological characteristics of the quality of life in the course of adaptive sports: author's abstract. dis ... kand. medical science / Khramov V.V. - Saratov - 2003. - 27 p.

7. Bouchard $\mathrm{C}$, Rankinen $\mathrm{T}$. Individual differences in response to regular physical activity. Med Sci Sports Exerc. 2001; 33: S446-S451.

8. Conyca W.J. Role of exercise in including increases in skeletal muscle fiber number if J.Appl. Physiol .: Respir. Environ And Exercise Physiol.-1980.-V.48- No. 3.-P. 421-426.

9. Hamilton R M., McLeod K., Houston A B., Macfarlane $\mathrm{P}$ W. Pediatric Electrocardiogram Diagnosis of left ventricular hypertrophy by computer and cardiologists evaluated using echo LVM. Eur. Heart J. Vol. 24, 2003, p. 604

10. Kubicek WG, Kamegis JW, Patterson RP, Witsoe DA, Mattson RH. Development and evaluation of an impedance cardiac output system. Aerospace Med 1967, 37: 1208-12

11. Lauer Michael S., Jiambo Li, Carolyn Apperson-Hansen, Claire E. Pothier, Eugene $\mathrm{H}$. Blackstone. Timing of Heart Rate Decay After Exercise and MortalitAmer. Coll. Cardiol., 2003, Vol. 41, Issue 6, Suppl. A

12. Lehmann M.J., Lormes W., Opitz Gress A. et al. Training and overtraining: An overview and experimental results in endurance sports // J. Sports. Med. Phys. Fitness. 1997. v. 37.- No. 1.- P. 7-17.

13. Vakhitov I.H. Catecholamine Excretion in Individuals Engaged in Extreme Sports / A.V. Izosimova, I.H. Vakhitov, T.L. Zefirov // INDO American Journal of Pharmaceutical Sciences. - 2017 - 4 (9). - P.

\section{0-3043.}

14. Vakhitov I. Kh. Changes in the blood shock volume among children with hypokinesia / B. I. Vakhitov, T. L. Zefirov, I. Kh. Vakhitov // Drug Invention Today Vol 10 - Special Issue 3 - 2018. - P. 3197 3199 .

15. Vakhitov I.Kh. Peculiarities of heartbeat rate and stroke volume of blood negative phase manifestation among young sportsmen after muscular load / B. I. Vakhitov*, I. Kh. Vakhitov, A. H. Volkov, S. S. Chinkin // Journal of Pharmacy Research. -2017, -Vol. 11, -P. $1198-1200$.

16. Kurmanali, A., Suiyerkul, B. Aitmukhametova, K., Turumbetova, Z., \& Smanova, B. (2018). Analysis of the proverbs related to the lexemes" tongue/language". Opción, 34(85-2), 97-115.

17. Yazdekhasti, A., Erfan, N., \& Nazari, N. (2015). Investigating the Relationship between Spiritual Intelligence and Social Adaptation among Girl High School Students in Shahreza City. UCT Journal of Social Sciences and Humanities Research, 3(1), 20-23. 